\title{
Assessing Households' Willingness to Pay for Improved Solid Waste Management Services in Jigjiga, Ethiopia
}

\author{
Abdi Shukri Yasin \\ Department of Natural Resources Management, Kabridahar University, Ethiopia
}

Received November 4, 2020; Revised January 25, 2021; Accepted February 7, 2021

\section{Cite This Paper in the following Citation Styles}

(a): [1] Abdi Shukri Yasin, "Assessing Households' Willingness to Pay for Improved Solid Waste Management Services in Jigjiga, Ethiopia," Environment and Ecology Research, Vol. 9, No. 2, pp. 39 - 44, 2021. DOI: 10.13189/eer.2021.090201.

(b): Abdi Shukri Yasin (2021). Assessing Households' Willingness to Pay for Improved Solid Waste Management Services in Jigjiga, Ethiopia. Environment and Ecology Research, 9(2), 39 - 44. DOI: 10.13189/eer.2021.090201.

Copyright $\mathrm{C} 2021$ by authors, all rights reserved. Authors agree that this article remains permanently open access under the terms of the Creative Commons Attribution License 4.0 International License

\begin{abstract}
This study examined household's willingness to pay for improved solid waste management services in Jigjijga town, capital of Somali Regional State, Ethiopia. Using a semi structured questionnaire, primary data were collected from 178 household heads in Kebeles 10, 16, 17, 7,5 and 8 that were selected purposively based on their income group. The socioeconomic data were analyzed using descriptive statistics while the independent variables were assessed using Logit Regression Model. The average willingness to pay amount was found to be nearly 4 United States Dollar (150 Ethiopian Birr), and the logit regression model results showed that income, and family sizes were statistically significant at $1 \%$, where occupation and quantity of waste generated were also statistically significant at $5 \%$. Furthermore, educational levels, period of stay, and environmental awareness of households were statistically insignificant. Lack of sustainable waste management financing is the major challenge (51\%) reported by waste managing bodies followed by household's unwillingness to pay, Inadequate protective equipment's of staffs, poor connection between the kebelle administration \& the waste collecting companies, less access to roads, and lack of recycling centers in the study sites. Private agencies should, therefore, be empowered via providing them incentives and necessary materials. Waste managing companies should increase the frequency of collection, while at the same time modifying their service price according to the average amount which most household are willing to pay. Finally, serious measures must be taken against households that illegally dispose their waste in unwanted places.
\end{abstract}

Keywords Willingness to Pay, Logit Regression Model, Solid Waste Management, Environmental Awareness, Semi Structured Questionnaire, Jigjiga, Ethiopia

\section{Introduction}

Solid Waste management has become an issue of increasing global concern as urban populations continue to rise and consumption patterns change [1]. Generation of Municipal Solid Waste (MSW) increases in line with developmental rate of any country [2].

Global waste was 2 billion tons in 2016 and could rise to 3.4 billion tons by 2050 with third of the world's waste dumped openly and not treated [3]. On the same note, countries especially in South Asia and Sub-Saharan Africa could reap economic and environmental benefits by better collecting, recycling and disposing of trash. According to [4] the picture of solid waste management varies in developing countries. Firstly, majority of the population are too poor to regularly afford fees for waste collection. Secondly, many of the people ignorantly dispose of waste carelessly with little concern about the imminent effects their careless disposal will ultimately cause. Thirdly, in some instances the people just do not think out the complexity of the waste problem and on whom the effect will finally rest. Households seem to think that it is completely the concern and major duty of the local administration to ensure proper waste management at no 
extra charge[5].

Available data show that 125 million tonnes per annum of municipal solid waste were generated in Africa in 2012, of which 81 million tonnes $(65 \%)$ were from sub-Saharan Africa and this is expected to grow to 244 million tonnes per year by 2025 [6]. The authors also revealed that with an average waste collection rate of only $55 \%$, nearly half of all waste generated in Africa, remains within our cities and towns, dumped onto sidewalks, open fields, storm water drains and rivers. This is because of Land filling, which has become the immediate most possible way of managing waste in most of the African countries and the authorities that primarily bear the responsibility to clean up the cities, towns and residential areas find it easier and time saving to collect the waste and carry it to a landfill rather than sorting out the wastes for recycling and composting [7].

Ethiopia is facing rapid urbanization per annum, leading to overcrowding and the development of slums and informal settlements with poor waste management practices resulting serious health, safety, and environmental consequences, where in 2016 alone, the country's generation of municipal solid waste totalled some 7 million metric tons [8].Solid waste in municipalities of Ethiopia has experienced traditional practices of collecting, disposing and reusing solid waste, which is not aimed at promoting public health, protection of the environment $\&$ other energy sources [9].

Effective solid waste management is becoming more and more important in Somali Region especially the capital of Jigjiga due to lower collection service and minimum coverage with much of the collected waste dumped in public areas, dry streams and in the city drainage [10]. Jigjiga City, like other cities in developing countries, faces problems associated with poorly managed solid waste operation with only $55 \%$ of the solid waste produced per day in Jigjiga town is collected and disposed by the Hormud SWM Company in the Sheik Ali Gure dumpsite that is $6 \mathrm{~km}$ away from the city center and the remaining $45 \%$ of the solid wastes is uncollected and dumped in unauthorized areas such as open fields, ditches, sewers, streets and many other available spaces in the city [11]. The authors also point out that the social waste collection service in the town is unsatisfactory, and scenes of scattered waste are common in most parts of the city which caused bad smells and attracted various disease vectors and pests resulting deteriorated aesthetic quality of the city.

As a result of this, Jigjiga residents have the opinion that the solid waste collection service is not functioning properly, and thus the locals are neither willing to cooperate with waste collectors nor willing to pay for the service.

In addition to this, there is no study that assessed Jigjiga resident's willingness to pay for improved solid waste management. A need, therefore, arises to evaluate households' willingness to pay for improved solid waste management services in Jigjiga town.

Even though similar studies [12-17]have been undertaken so far, this study's uniqueness is in that it did not only focus on the demand side but also examined the supply side issues by taking stock of the challenges faced by the local government and private companies currently engaged in waste collection and disposal in the study area. Furthermore, the study assessed attitude and behaviour of households towards the current solid waste collection service.

\section{Materials and Methods}

\subsection{Description of the Study Area}

Jigjiga Town, the capital city of Somali state, is located in the eastern part of Ethiopia. The city astronomically lies between $9^{\circ} 16^{\prime} 30^{\prime \prime}$ to $9^{\circ} 24^{\prime} 30^{\prime \prime} \mathrm{N}$ latitude and $42^{\circ} 44^{\prime} 0^{\prime \prime}$ to $42^{\circ} 51^{\prime} 0^{\prime \prime}$ E longitude (Figure 2). The town is almost located on flat land with gentle slopes and subtropical agro-ecological zone depicting an average temperature of $12.27^{\circ} \mathrm{C}$. Mean Annual Rainfall of $712 \mathrm{~mm}$ is attributable to Jigjiga town and its vicinity. The minimum and maximum rainfall of the town lies between $400 \mathrm{~mm}$ and $800 \mathrm{~mm}$. The town is $625 \mathrm{KM}$ 's away from Addis Ababa, the capital of Ethiopia.

According to [18], population of Jigjiga Town has been estimated to be 385,534 of whom 200,612 are males and 184,922 are females. Estimating an average of 6.4 individuals per household, the town has about 60,240 households. Being the largest town in the eastern rim of the country, it is the hub of various businesses and office establishments and educational institutions including Jigjiga University [11]. 


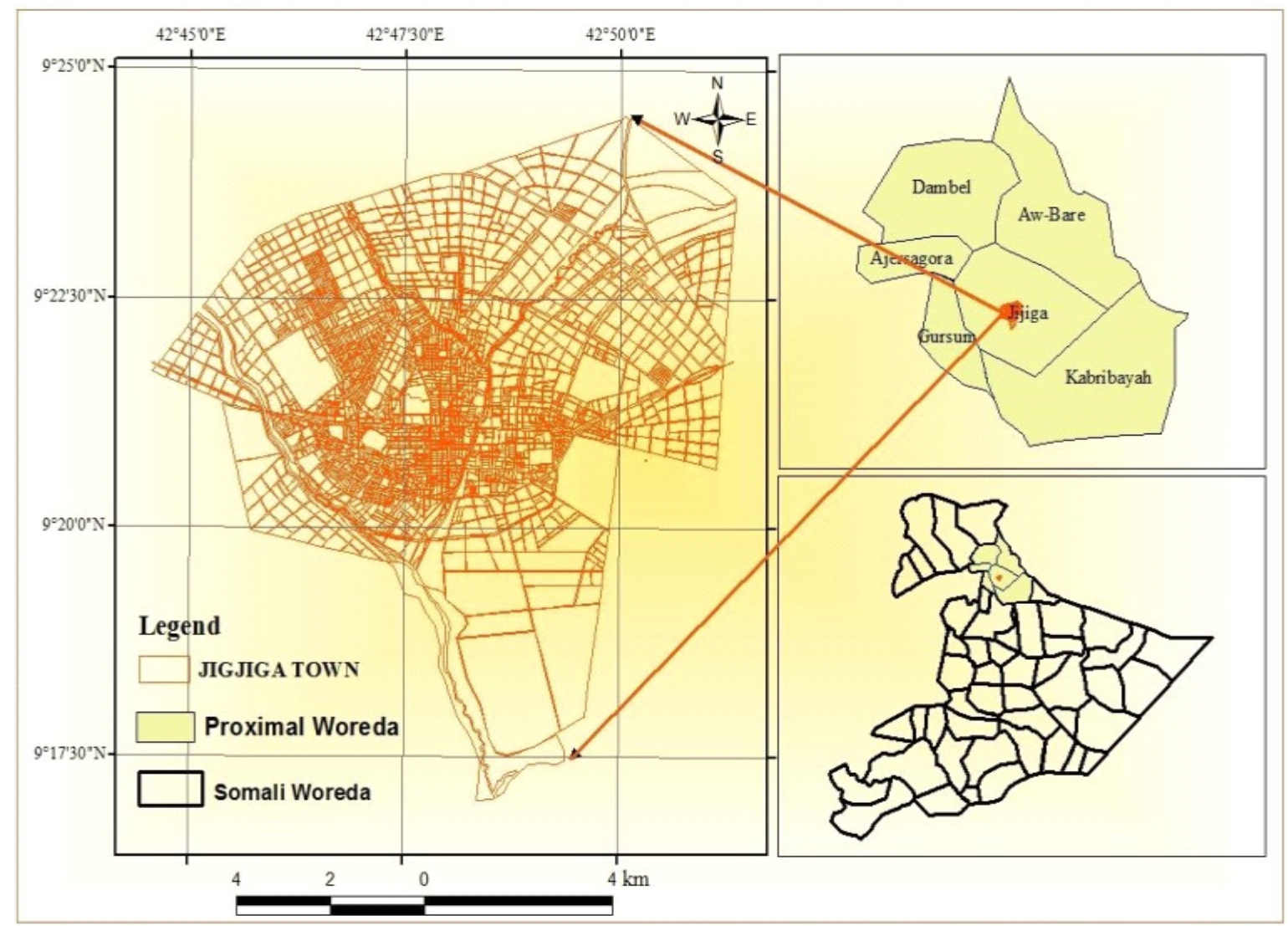

Figure 1. The Study Area

\subsection{Research Design, Sampling Technique and Methods}

Both probability and non-probability sampling techniques were used for this particular study. Jigjiga town was purposively selected based on its expansion and booming population where greater solid waste production data is easily accessible and this made it relevant for the study. The town consists of 20 Kebeles, and among these, kebeles $05,08,17,7,10$, and 16 were purposively selected based on their relative income group. Finally, Simple Random sampling method was used for the selection of the sample respondents.

Table 1. Household Population \& Sample size per Kebelle using probability proportional to sample size

\begin{tabular}{|c|c|c|c|}
\hline $\begin{array}{l}\text { Names of } \\
\text { Kebeles }\end{array}$ & $\begin{array}{c}\text { No. of } \\
\text { Households }\end{array}$ & $\begin{array}{c}\text { Sample } \\
\text { Size }\end{array}$ & $\begin{array}{c}\text { Relative } \\
\text { Income Group }\end{array}$ \\
\hline 10 & 6,525 & 46 & \multirow{2}{*}{ High income } \\
\hline 16 & 3,335 & 24 & \\
\hline 17 & 3,731 & 26 & \multirow{2}{*}{ Middle income } \\
\hline 07 & 5,017 & 35 & \\
\hline 05 & 4,785 & 34 & \multirow{2}{*}{ Low income } \\
\hline 08 & 1,777 & 13 & \\
\hline Total & 25,170 & 178 & \\
\hline
\end{tabular}

Source: Own Computation, 2020.
Primary data were gained from cross-sectional survey of 178 household heads, and focus group discussion with waste managing agencies, while secondary data were gained from reviewing existing literature. Both qualitative and quantitative types of data were considered for the study. Descriptive statistics was used for analyzing household characteristics, and the logit regression model was used to determine the household's willingness to pay for improved waste disposal service. SPSS Version 20 tool was used to regress the willingness to pay against the independent variables.

\section{Results}

\subsection{Socio-economic Characteristics of the Respondents}

The mean average age and income of household's were 51 years and 143 USD (5500 Birr) respectively. Majority of the respondents were Male (91\%), where female number was minimum (9\%). A substantial number, $85.4 \%$, of the participants were married. The remaining $8.4 \%$ and $6.2 \%$ were widow and divorced respectively. In terms of the average education level, a majority (50\%) of the household heads were illiterate. Less than half of the respondents (38.2\%) were merchants, and $27 \%$ of the households were 
unemployed. Regarding the family size of the respondents, about 31 percent of the respondents have 6-10 family members, and most of the participants stayed in the study area for more than 10 years.

\subsection{Solid Waste Production and Collection Service of the Study Area}

Waste production of Jigjiga town is increasing because of the booming population with six to ten being the average family size with 11-15 sacks of waste produced per month at each household. Almost all of the respondents in the study area get the SWM service from either the municipality or the private companies three times a month $(70 \%)$, followed by those who get the service once a month $(18 \%)$, twice a month (6\%), four times and above (nearly 6\%). Approximately 3 United States Dollars (100 Ethiopian Birr) is the average amount (82\%) households pay for the waste collection service, while the remaining households (18\%) also pay 1 USD (50 birr) for the waste collection service.

There is also totally no segregation of wastes both at household level and at collector's level, and almost all of the collected waste is transported through trucks directly to the Sheik Ali Gure dumpsite.

\subsection{Residents' Behavior \& Attitude towards Solid Waste Collection Service in Jigjiga}

Most of the households (93.3\%) have storage receptacle (Sacks) of their own where they temporarily store the waste till collectors take it. 11-15 sacks (closely 45 percent) is the average quantity of waste households generate per month. Collectors take the waste of most households ( $76 \%$ ), where the remaining households throw their waste in running rain water, ditches/streets/spaces, and/or burn it. Environmental awareness of most of the participants (67.4\%) is also found to be low.

On the other hand, more than half of the households (nearly 54\%) requested "Every day disposal" as new solid waste service they would love to have made available to them in the future. Some have also raised services like recycling programs, and modern storage receptacles. Most of the participants $(67.4 \%)$ voted for private companies as the best agency to handle the waste management in the town with the strong belief that private companies keep time, and are accountable and responsive. Finally, majority of the households are not satisfied with the service, that is why most of them strongly agree that improved solid waste management is a necessary measure that the city should take up.

\subsection{Residents' Willingness to Pay for Improved SWM in Jigjiga}

From the total 178 household heads surveyed in this study, significant numbers (149) are willing to pay if the services are to be improved. Nearly 4 USD (150 birr) is the average WTP $(70.2 \%)$. The higher willingness to pay amount implies how Jigjiga residents are thirsty for sustainable solid waste management.

In addition to this, from the 29 households that were not willing to pay, more than half of them (18 HH's) noted that they can't pay because they are poor. 9 of them believed that the money charged is very high, while only 2 of them were satisfied with the current SWM service.

Table 2. Residents' WTP for improved SWM in Jigjiga

\begin{tabular}{ccc}
\hline Variables & Frequency & Percentage \\
\hline WTP & & \\
Yes & 149 & 83.7 \\
No & 29 & 16.3 \\
Total & 178 & 100.0 \\
Amount & & \\
100 & 24 & 13.5 \\
150 & 125 & 70.2 \\
Total & 149 & 83.7 \\
\hline
\end{tabular}

Source: Own Survey, 2020.

\subsection{Logistic Regression Results}

The logistic regression results indicate that household's income, family size, occupation and quantity of waste generated were statistically significant, where household's educational level, environmental awareness and period of stay were statistically insignificant.

Compared to those who are from low-income group, the high-income group is more likely to pay more for improved waste collection services. The rich are likely to pay more by a factor of 9.83 as compared to the poor and is statistically significant at $1 \%$ significance level. As family size increases, the likelihood of paying more for improved waste disposal services decreases by a factor of 0.13 . This variable is also statistically significant at $1 \%$ significance level.

Those unemployed ( 0 ) are likely to pay less than those who are engaged in some occupation (1 to 5). The unemployed are less likely to pay more by a factor of 0.121 compared to those employed in one form or another and this variable is statistically significant at $5 \%$ significance level. Furthermore, households with higher quantity of waste are likely to pay more for improved solid waste management by a factor of 3.275 than those with lower quantity of waste. And this is statically significant at $5 \%$ significance level.

Even though it is common in environmental economics literature that people's educational level, environmental awareness and period they stayed at houses have significant effect on their willingness to pay for improved solid waste management services, but according to this study, these variables are not statistically significant at $1 \%$, $5 \%$, and $10 \%$. And this could be due to the smaller sample 
size of this constrained by limitations like time, budget and scope.

Table 3. Logistic Regression Results of WTP

\begin{tabular}{ccccc}
\hline Variables & B & S.E & Sig. & Exp (B) \\
\hline INCM & 2.293 & 0.803 & $0.000^{* * *}$ & 9.836 \\
FMSZ & -2.03 & 0.773 & $0.000^{* * *}$ & 0.132 \\
EDUC & 1.536 & 0.372 & 0.654 & 4.624 \\
OCCP & -2.117 & 0.671 & $0.009^{* *}$ & 0.121 \\
STAY & 1.682 & 0.783 & 0.07 & 5.349 \\
QWST & 1.19 & 0.168 & $0.021^{* *}$ & 3.275 \\
EAWR & 1.542 & 0.261 & 0.253 & 4.652 \\
Constant & 1.569 & 0.302 & 0.003 & \\
\hline
\end{tabular}

$* * *$ represent $1 \%$ S.L, $* *$ Significant at $5 \%$,

Log likelihood $=95.017, \mathrm{~N}=178$, Chi-square $=11.290$ Source: Own Computation, 2020.

\subsection{Challenges Facing the Municipality and Private Companies Involved in Waste Management}

Lack of sustainable SWM financing is the major challenge $(51 \%)$ reported by the heads of private companies and municipality currently engaged in waste collection service of the study site. The only source of income for waste managing companies is households with zero external funds, considering Household's unwillingness to pay being the second major challenge $(20 \%)$ revealed in the study. The remaining percent consists of Inadequate Protective equipment's of staffs $(12 \%)$, poor connection $\mathrm{b} / \mathrm{n}$ the kebelle administration \& the waste collecting companies (9\%), less access to roads $(7 \%)$, and lack of recycling centers in the town $(1 \%)$.

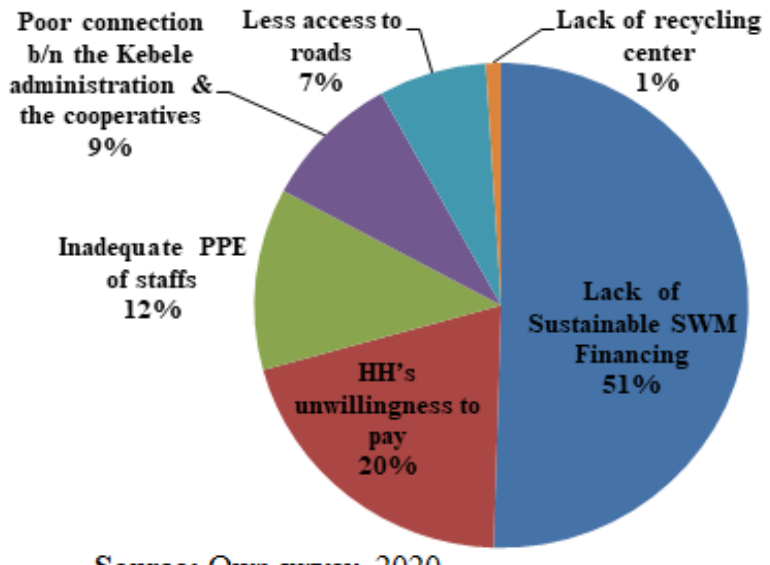

Source: Own survey, 2020.

Figure 2. Challenges faced by waste managing agencies

\section{Discussion}

The study found that almost all of the respondents get the solid waste service from either the municipality or the private collectors and this reveals that there is worth mentioning vast initial stage waste management service in Jigjiga town but with very lower collection frequency. There is also illegal disposal of waste reported in the study which is a serious threat not only to the surrounding environment but also to animals and humans nearby. Furthermore, Environmental awareness of most participants is found to be low. And this is why majority of the households don't recycle their waste. Most importantly, majority of the household are not satisfied with the current solid waste service of the town mainly due to lower waste collection. That is why majority of the households' are willing to pay more for improved solid waste collection and disposal services.

The logit results found that Household's income and family size were statistically significant at $1 \%$ as also found by [15] where occupation and quantity of waste generated were statistically significant at $5 \%$.The study gave emphasis not only on the demand side but also examined the supply side issues by taking stock of the challenges faced by the local government and private companies currently engaged in waste collection and disposal in the study area. This new concept is contributed to the existing resource economics literature. On the other hand, the higher average willingness amount will help waste management agencies amend their service price amount. The institutional challenges mentioned in this study will help the waste managing agencies get national and international attention. Finally, this study did not asses all that factors that affect household's willingness to pay for improved solid waste management service. Therefore, future researches should include explanatory factors (like Household knowledge on Solid waste) which may influence the results differently.

\section{Conclusions}

This research aimed to assess household's willingness to pay for improved solid waste management in Jigjiga town, Ethiopia. Major findings reveal that environmental awareness of respondents is found to be very low, that is why they neither recycle nor take any measures to reducing their household's wastes. Almost all of the respondents in the study area get the service with an average payment amount of 100 birr. Majority of the household heads surveyed in this study are willing to pay an average amount of 150 birr for improved solid waste management service. This higher willingness to pay amount indicates how Jigjiga residents are thirsty for sustainable solid waste management. Based on the logistic regression results, it can be concluded that household's income, family size, occupation and quantity of waste generated were statistically significant, where household's educational level, environmental awareness and period of stay were statistically insignificant. Furthermore, the major challenges tackling waste managing organizations in the 
study area are lack of sustainable Solid Waste Management financing, some household's unwillingness to pay, Inadequate equipment's of staffs, poor connection between the Kebelle administration \& the waste collecting companies, less access to roads, and lack of recycling centers in the study sites. Waste managing agencies should, thus, modify their service price according to the average WTP amount, increase the frequency of collection, and raise periodic environmental awareness to the community so that people will develop a better understanding about SWM. The private waste managing agencies should also be empowered via helping them get sustainable budget for the waste collection service. Serious measures against illegal disposal must be put in place. Finally, this study did not asses all the factors that affect household's willingness to pay for improved waste management; future researches should therefore include variables (like household's knowledge on solid waste management) which could anyhow influence the results.

\section{Acknowledgments}

All thanks be to Allah, who enabled me accomplish this research paper. I always seek his ultimate guidance, help and blessings. I am very grateful to Dr.Oumer Nuru and Prof. Dhananjaya for their constructive suggestions and comments to improving this paper. I am also very much indebted to Kabridahar University's Research Publication Directorate for covering the publication fee of this paper. Thank you all indeed.

\section{REFERENCES}

[1] Rachael E.M, and Khosrow F, "Systems approaches to integrated solid waste management in developing countries," ELSEVIER, Vol.33, No.4, pp. 988-1003, 2013.

[2] Muzenda E, Belaid M, Mollagee M, Motampane N, Ntuli F, "Reflecting on Waste Management Strategies for South Africa," World Congress on Engineering and Computer Science, Vol.2, pp. 19-21, 2011.

[3] World Bank, "Brief, Solid waste management," The World Bank, 2019.

[4] Sichiweza, E, "Master Thesis, Participation of Households In Solid Waste Management And Circular Economy Towards Sustainability: A Case Study Of Kabwe Town, Central Province of Zambia"2017.

[5] Bournay, E, "Waste, Recyclers and Recycled: Planet in Peril, An Atlas of current threats to people and the environment, England" UNEP/GRID, 2006.
[6] Scarlat, N., Motola, V., Dallemand, J. F., Monforti-ferrario, F., \&Mofor, L, "Evaluation of energy potential of Municipal Solid Waste from African urban areas," Renewable and Sustainable Energy Reviews, Vol.50, pp. 1269-1286, 2015.

[7] Rotich, H. K., Yongsheng, Z. \& Jun, D, "Municipal solid waste management challenges," NCBI, Vol.26, No.1, pp. 92-100, 2006.

[8] Zhaohua Wang, Bin Zhang, Jianhua Yin, \& Xiang Zhang, "Willingness and behavior towards e-waste recycling for residents in Beijing city," China. Journal of Cleaner Production, Vol. 19, No.2011, pp. 977-984, 2011.

[9] Hailemariam, M., \&Ajeme, A, "Solid waste management in Adama, Ethiopia: Aspects and challenges" International Journal of Environmental, Ecological, Geological and Geophysical Engineering, World Academy of Science. Engineering and Technology, Vol.8, No.9, pp.603-609, 2014.

[10] Plus, O. N. E. W., \& Region, S, "Solid waste management in Jijiga," Somali Region Baseline survey factsheet Household solid waste practices, p.p 1-6, 2016.

[11] Yohanis Birhanu, and Genemo Berisa, "Assessment of Solid Waste Management Practices and the Role of Public Participation in Jigjiga Town, Somali Regional State, Ethiopia," International Journal of Environmental Protection and Policy, Vol. 3, No. 5, p.p 153-168, 2015.

[12] Muniyandi Balasubramanian, "Household Willingness to Pay for Improved Solid Waste Management Services: Using Contingent Valuation Analysis in India," IntechOpen, p.p 1-15, 2019.

[13] Boateng, K. S., Agyei-Baffour, P., Boateng, D., Rockson, G. N. K., Mensah, K. A., \&Edusei, A. K., "Household Willingness-to-Pay for Improved Solid Waste Management Services in Four Major Metropolitan Cities in Ghana, "Journal of Environmental and Public Health, Vol. 2019, p.p 1-9, 2019.

[14] [14] Adepoju, A., \&Salimonu, K, "Household Willingness to Pay for Improved Solid Waste Management in Osun State, Nigeria," Semantic Scholar, pp. 1-10, 2011.

[15] Dika, G., Nemie, A., \& Birhane, E, "Household's Willingness to Pay for Improved Solid Waste Management in Gulelle Sub City, Addis Ababa," Energy and Environmental Engineering, Vol. 6, No.1, pp. 1-7, 2019.

[16] Arekere, D.M, "Examining solid waste management issues in the City of Bryan. Doctoral Dissertation," OAKTrust, pp. 1-164, 2006.

[17] Krishnal Thirumarpan and MSA Dilsath, "Household Willingness to Pay for Improved Solid Waste Management In Batticaloa, Sri Lanka,” Tropical Agricultural Research \& Extension, Vol.18, No.2, pp. 1-11, 2015.

[18] Ethiopia Central Statistical Agency, "Federal Demographic Republic of Population Projection of Ethiopia from 2014 2017," CSA, pp.1-118, 2013. 